\title{
Conflict Settlement in the Register Forest Areas of Lampung Province
}

\author{
Hieronymus Soerjatisnanta ${ }^{1}$, Fransiscus Xaverius Sumarja ${ }^{2}$, Ricco Andreas ${ }^{3}$ \\ \{s.nymus@yahoo.co.id ${ }^{1}$,fxsmj.unila@gmail.com², Andreasricco@gmail.com $\left.{ }^{3}\right\}$ \\ Lecturer at the Faculty of Law University of Lampung, Lampung, Indonesia ${ }^{1}$, Lecturer at the Faculty of Law \\ University of Lampung, Lampung, Indonesia ${ }^{2}$, Researcher at the Center of Public Policy and Human Right \\ Studies Faculty of Law University of Lampung, Lampung, Indonesia ${ }^{3}$
}

\begin{abstract}
Abstact. The register forest area in Lampung Province has a long history of conflict, starting from forest use that was not in accordance with the function of the forest. Lampung Province has three forms of forest, namely; conservation forest, protection forest, and production forest which have different conflict characteristics. The problem is that in all 51 register forest areas, conflicts frequently and repeatedly occur, requiring permanent resolutions. The government has issued a policy of social forestry through Presidential Regulation No. 88 of 2017 concerning Settlement of Land Tenure in Forest Areas. The researcher summarizes two legal issues, namely: (1) how is the typology of conflict in the register forest area in Lampung Province? (2) How is the implementation of the social forestry program as a form of conflict resolution in the register forest areas of Lampung Province? The researcher use legal or empirical sociology methods to answer these problems, including research on legal identification (unwritten) and research on the effectiveness of law in society. The results of the study provide the answer that, first, the implementation of social forestry must observantly regard the characteristics of conflict and forest function so that the social forestry scheme can truly become a bridge to resolve conflicts that occur in the register forest areas of Lampung Province. It must be said that the social forestry that currently exists is not a 'panacea' in all kinds of conflicts in the Lampung Province registers Partnership Not Panacea. Social Forestry Schemes must consider forest function, legal, social, economic, cultural, and political aspects, and identify protected forests starting from: (1) communities, (2) register land tenancy, (3) village officials, (4) security apparatus, and (5) the government. Meanwhile, In production forests, the aspects to concern are: (1) investors, (2) land providers, (3) land cultivators, (4) partnership groups, (5) non-partnership groups, (6) thugs, (7) companies, (8) security officials, and (9) the government. Second, the register forest areas of Lampung Province can only run with two schemes, namely Community Forestry and Forestry Partnership, because other forest functions do not exist in Lampung Province. The evaluation of the social forestry program implementation is deliberately required to improve the subsequent implementation of the program and to become a bridge for conflict resolutions.
\end{abstract}

Keywords: Resolution, Conflict, Forest, Lampung Province 


\section{Introduction}

The registered forest area in Lampung Province has a long history of conflict.[1],[2] Forest areas began to be established in the Dutch colonial government, divided into three periods, namely, the first period during the Dutch colonial period, the second period during the independence period, and the third period on the application of the concept of agreed forest use followed by the concept of regional spatial planning ( RTRW). Forest designation began in 1922 to 1942, and has been completed (51 registers). The term register is taken from the word forest registration (register) for naming forest areas in the Lampung region.

The registered area itself is divided into three types of forest functions, namely conservation forest, protection forest and production forest.[3]; Forests based on their functions (Article 6 and Article 7 of Law Number 19 Year 2004 concerning Stipulation of Government Regulations in Lieu of Law Number 1 of 2004 concerning Amendments to Law Number 41 of 1999 concerning Forestry into Law) [1].

The problem is, all forest areas (51 registers) have a conflict.[4] In 2013 the conflict in the registered forest area became more massive,[5] the government issued a partnership program policy based on Permenhut Number 39 of 2013 concerning Partnership, which was renewed by Permenhut Number P.83/menlhk/setjen/kum.1/10/2016 concerning Social Forestry, and strengthened by Presidential Regulation Number. 88 of 2017 concerning Settlement of Land Tenure in Forest Areas [6].

In Articles 10 and 11 of Presidential Regulation Number 88 of 2017 concerning Settlement of Land Tenure in Forest Areas, it has been stipulated that one of the models for settling land tenure in forest areas is through the Social Forestry Program. According to Presidential Regulation Number 88 of 2017 concerning Settlement of Land Tenure in Forest Areas, Social Forestry is a sustainable forest management system implemented in state forest areas or private / customary forests carried out by local communities or customary law communities as the main actors to improve welfare. Balance of environment and socio-cultural dynamics. classified into five forms, namely: a) Village Forest (HD), b) Community Forest (HKm), c) Community Plantation Forest (HTR), d) Forestry Partnership (KK), e) Customary Forest (HA) which has different forest function characteristics [7].

During the reform period, the number of people looking for their lives around the registered forest area and in the registered forest area cannot be denied because inequality in permits and access has created many conflicts, until 2011 the conflict in the registered forest area widened, such as: in the forest area register 45 Mesuji District, in the area. protected forest register 22 Way Waya, Pringsewu Regency, in the forest area of register 44 Gunung Terang, which is part of Tulang Bawang Barat and Way Kanan districts, and in the forest area register 40 Gedung Wani, South Lampung [8].

The government is pushing a program to accelerate the implementation of social forestry to communities around forests, including in Lampung Province, so that they have the opportunity to manage forest areas economically but still follow the rules to guarantee the ecological function of the forest area in question. The goal is for the community to increase their income and become more prosperous, and the forest area, in addition to maintaining its function and sustainability, also truly provides benefits for the surrounding community. 
The government offers schemes in social forestry as a solution to the resolution of register forest conflicts.[9] Meanwhile, each register has different conflict characteristics and different forest functions, the fact is that it becomes a new problem when the journey is not as expected by the community, it is felt that it does not provide welfare [10][11][12][13]. Social forestry is not considered a panacea for all kinds of conflicts that have occurred in the registered forest area of Lampung Province [14][15][16].

This research is to re-identify the conflict characteristics of 51 registers in Lampung, starting from: (a) actors, (b) interests, (c) company business, (d) institutions, and (e) conflicting parties. It is hoped that it will produce a typology of conflict characteristic maps in each registered forest, which can be used as a reference in the formulation and peace policy of conflict resolution in registered forests. The legal issues in this research are: (1) What is the typology of conflict in the registered forest area in Lampung Province? (2) How is the social forestry program implemented as a form of conflict resolution in the registered forest area in Lampung Province?

\section{Methods}

Researchers use legal or empirical sociology methods to answer these problems, which include research on legal identification unwritten and research on the effectiveness of law in society [17]. With the approach used is, the first stage of Systematic Literature Review (SLR)[18] which identifies, assesses, and interprets all findings on a research topic, to answer research questions[19] by examining SLR with register social symptoms (conflict), identifying conflict characteristics, so that a typology of conflict can be found that has a different character. The second stage is the sorting of legal materials and regulations and justification. The third stage is indepth interviews with related sources.

Conducting field interviews in a formal way through a letter sent to the relevant agency and an internal approach to visit the informants directly, so that the data or information collected can be extracted properly, by preparing a list of questions about the identification and challenges of resolving forest conflicts in the register of Lampung Province. Targeted interviews include:
a. Actor
b. Investors
c. Company
d. Forestry and Environment Service of Lampung Province
e. Local Government
f. Parties to the conflict who are involved directly and indirectly.

\section{Result and Discussion}

Forest conflicts have started to appear since the re-establishment. This is because the determination was in principle only to re-establish the areas that had been determined during the Dutch colonial administration, not to rearrange the registered forest area in Lampung Province. Even though after independence the conditions were far different at that time, exacerbated again during the 1998 reform period, many people occupied forest areas that were previously managed 
by companies with land use permits, because of the inability of the community to find life outside the forest area. And make use of existing forest resources for their needs. The conditions and situations in the forest area in Lampung Province today are far different, so it is necessary to identify and use a new forest that can accommodate the community in accessing forest resources in the registered forest area of Lampung Province.

The process of designating forest areas through the determination of TGHK at the macro level at the provincial level, then continued with the confirmation of TGHK at the micro level in the form of delineation at the field level for each forest area unit. Implementing this forest area ganzzetement activity is the Sub-Center for Forest Inventory and Mapping (SBIPHU) which is a technical implementing unit under the Forestry Office. This inauguration was then endorsed by the district boundary committee, the Head of the Forestry Office, the Governor and the Minister of Forestry. Further activities which are then carried out periodically are boundary reconstruction which is carried out every 2-5 years.

As a result, these areas are no longer suitable and cannot fulfill their function as forests. Although the Regional Government and the Forestry Office have carried out what is called "paduseration" between TGHK and RTRW, in principle this activity is merely an attempt to resolve mismatched use of land between government agencies due to the policy of determining forest areas. And in the slightest it does not resolve land use conflicts between the government and the people on the ground [20].

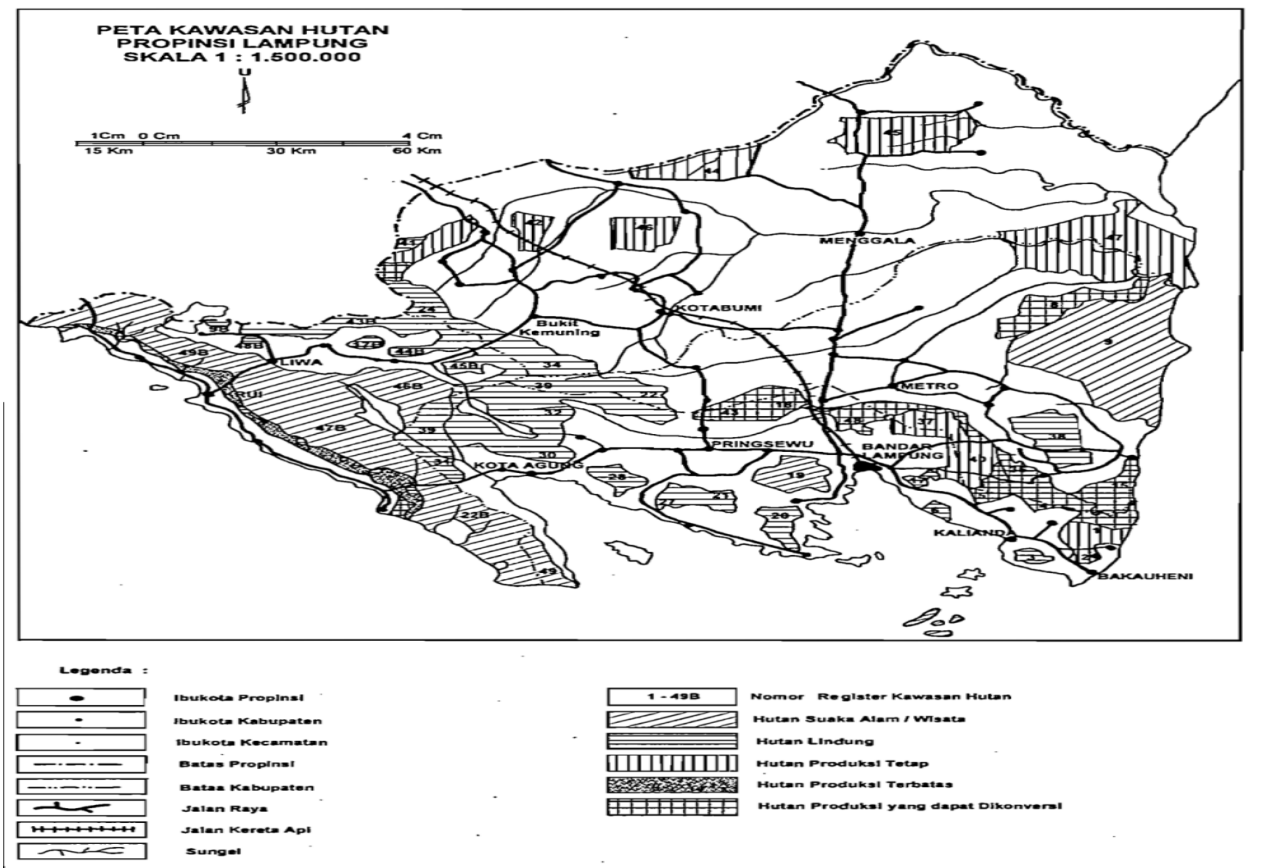

Figure 1. Map of the registered forest area of Lampung Province in 1990 


\subsection{Typology of conflict in registered forest areas in Lampung Province}

Land is an important subject that is often a source of conflict among stakeholders, including between government agencies at the central and regional levels between local communities and the government and local communities and companies holding concessions / licenses granted by the government. Furthermore, the typology of conflicts related to land or in this case the registered forest area can be described as follows:[21] a) The conflict between indigenous peoples and the Ministry of Environment and Exodus occurred as a result of the designation and/or designation of a customary area as a state forest area; b) Conflict between communities vs. Ministry of Environment and Forestry Ministry of Agrarian and Spatial Planning/BPN. For example, a conflict in the issuance of proof of land rights in areas classified as forest areas; c) Conflict between Ministry of Agrarian and Spatial Planning/BPN vs. Community. For example a conflict due to a transmigration program carried out in a forest area; d) Conflict between immigrant farmer communities vs. Ministry of Environment and Forestry vs. Local Government. For example, a conflict is caused by a wave of immigrant farmers who enter the forest area and carry out agricultural activities in the area; d) Conflict between village communities vs. Ministry of Environment and Forestry. For example a conflict because a forest area enters the village area; e) Conflict between land brokers vs. political elite's vs. peasants vs. Ministry of Forestry vs. BPN. For example, a conflict is caused by land brokers/brokers who are generally supported by mass organizations/political parties who sell and buy forest land and help issue certificates on that land; f) Conflict between local (custom) communities vs. permit holders. Although this occurs as a result of the Ministry of Forestry making unilateral claims over forest areas and granting rights to use them to permit holders, this typology is often triggered by restrictions on community access to forests by permit holders; g) Conflicts between forestry permit holders and other permits such as mining and plantations; and $\mathrm{h}$ ) Conflict due to the combination of various actors 1-8.

It can be described, a characteristic of each registered forest area that has differences ranging from forest function, conflict typology, parties that are interconnected and have their respective roles, and a social forestry scheme. There are many problems in the registered forest in Lampung Province, so we must look at the relationship between the parties, resolving from vertical conflicts to horizontal conflicts that occur in the registered forest.

There are many parties that must be clearly mapped from each party's relationship, such as in protected forests: 1) communities, 2) registered land cultivators, 3) village officials, 4) security forces, 5) government. In production forests, starting from: 1) investors, 2) land providers, 3) land cultivators, 4) partnership groups, 5) non-partnership groups, 6) thugs, 7) companies, 8) security forces, 9) Government. These actors have a long-standing relationship with each other, such as between thugs and the community, people have to pay security money to preman for security by the community, if they do not pay then the community will be subject to sanctions forcibly revoked their work or a riot occurs they will not Providing security assistance, things like this must also be considered in resolving conflicts through social forestry, identification in each forest register is necessary, if you want to implement social forestry in the Forestry and Community Forestry Partnership scheme in Lampung Province.

The implementation of social forestry raises many new problems in the Forestry Partnership scheme that is already running, the fact is that many farmers refuse, they feel they do not provide welfare as happened and have already been running in the Lampung Province register, social 
forestry is not considered a panacea for all kinds of conflicts that occur in the registered forest area of Lampung Province.[11],[12]

Law as a means of social integration, it will not be possible to work in a vacuum. According to Harry C. Bredemeier,[22] when the law operates in a social order, it will always get input from other fields such as economics, politics and culture. The intake received by the law becomes the input (input) and output (output) which is returned to society. Furthermore Harry C. Bredemeier said that is why law in reality functions as a factor for integrating society, so law must be able to resolve conflicts in an orderly manner, as stated by Bredemeier:[22]

"The law function of the last is the orderly resolution of conflict. As this implies, "the law" (the clearest model of which J. Shall take to be the court system) is brought into operation after11 there violet by someone else".

\section{Conflict position pattern}

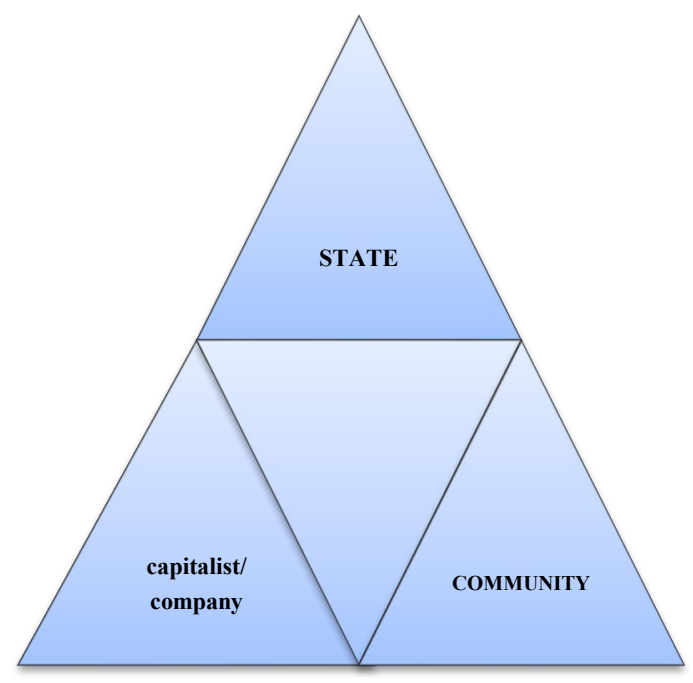

Figure 2. Conflict position pattern

Chambliss and Seidman make legal distinctions according to "a typology of society based on consensus on values" with a "typology of society based on conflict" [23]. Therefore, in handling conflict, it is necessary to have a legal instrument that can balance the three parties that can be accepted by all stakeholders, in this case the registered conflict in the social forestry scheme.

\subsection{Implementation of social forestry programs as a form of conflict resolution}


Community Forest, hereinafter abbreviated as $\mathrm{HKm}$, is a state forest whose main use is aimed at empowering the community. Community forestry $(\mathrm{HKm})$ is granted to groups or associations of local community groups in the form of a community forest utilization business license (IUP-HKm) which the decision is issued by the Minister of Environment and Forestry. The governor can issue IUPHKM SK if it meets the requirements set by the Minister of Environment and Forestry Regulation. Community forest managers are residents who live in the vicinity of the forest area who are members of a group or association of local forest management groups, whose names are known and signed by the village head / village head.[7, hal. 17]

There are several stages in the partnership journey and problems in the forest register 45 Mesuji Lampung in each stage in the community groups that carry out the partnership, including:

a. The first stage, the community drew a high cut of the harvest.

b. In the second stage, the community had to wait a long time to be able to replant because they had to get approval from the company.

c. The third stage, the income they get decreases because the sales have to be sold to companies that have been determined by the partnership team even at a low price.

d. The fourth stage, a sugarcane trial is conducted which inevitably the community must follow.

The profit sharing model in partnership with one harvest for the cultivator gets 8 million with a target of 8-10 months. Because the harvest results will be reduced the cost of purchasing seeds, cleaning the grass, using a large plow. From the data obtained, the first phase of the partnership covers an area of 1080 ha. with details of 400 ha of cassava. 96 ha of acacia hardwood trees are managed, 33 ha of sugarcane, and currently only 400 ha are planted with partnerships.

Forestry Partnership is a form of cooperation between the community and certain parties who have/hold forest management rights/forest exploitation rights / forest utilization rights as well as forest area lease-to-use permit/ forest product industrial business permits. Where this collaboration is the obligation of the right or permit holder to involve the community around the forest area which is the area of management of the right/permit holder [7,pp. 25-26].

In relation to the model of changes in the designation of functions and management systems of forest areas, it is in fact already in accordance with the contents of Article 58 to article 61 of Law No. 19 of 2013 concerning Protection and Empowerment of Farmers. That the government is obliged to guarantee agricultural sales for farmers, especially the ease of obtaining Free State land designated as an agricultural area of up to 5 hectares to local farmers who have been farming for 5 consecutive years. The aforementioned convenience is given to local farmers who do not own land but have cultivated land designated as agricultural land for 5 consecutive years, and for farmers who have less than 5 hectares of agricultural land. The provision of convenience to farmers as referred to above is provided in the form of lease rights, management permits, management permits and utilization permits. The mandate of this law is actually in line with the social forestry model through changes in the designation of functions and the forest area management system. There is an alternative to providing legal certainty over land controlled by farmers as long as it is on former state land. However, what needs to be paid attention is to be careful in implementing the procedures for giving programs to these farmers, so as not to violate the prevailing laws and regulations. 


\subsection{Evaluation of Social Forestry (social Forestry) 3.3.1 Direction of Social Forestry Policy}

With regard to social forestry-based forest area management system policies, decision makers should change the way (mindset) and actions in forest area management, so that forest area management system policies are not only oriented to economic aspects, but also pay attention to social aspects and more importantly. namely environmental and social aspects.

Environmental damage is inseparable from the pattern of social structures and social systems in which individuals / groups interact, environmental problems cannot possibly be explained in the individual's internal motivation, but more importantly it is a product of system movement that is proven to be anti-ecological. Because after all, between social reality and ecological reality are clearly related. The influence of religious aspects, political aspects, economic aspects, educational aspects, and other aspects, are clearly involved in determining the good and bad of natural resources and environmental features. Forest destruction and the absence of proper environmental conservation are one of these aspects. Thus, in the management of forest areas including forest utilization, this system approach is important. considering forestry issues, especially related to social forestry policies for forest area management, it is certain that this will affect various other components of the system.

Therefore, environmental considerations with all related aspects in it must always be the concern of all stakeholders (Ministry of Environment and Forestry and its ranks below) as development actors and decision makers who have the most authority in implementing this model Policy makers when considering a decision, will If nature gives approval to changes in the forest area management system or not, it must be fully aware that whatever is done or not done will have consequences for various components of the environmental and social system as a whole.

Another aspect that is no less important is law enforcement on violations of statutory regulations, settlement of land tenure in forest areas through the Social Forestry Program tends to be more prone to abuse of authority and / or acts of violating environmental law principles, especially those related to environmental and social preservation of the community. In the policy of changing the forest area management system, it is necessary to carry out careful studies and preparations, both concerning instruments for regulating the issue of synchronization and harmonization), implementing the principle of preserving environmental functions in its policies, integrating policies across sectors, across regions and across stakeholders, anticipating irregularities. or violations in the field, or abuse of authority of those involved in decision making.

\subsubsection{Community Participation}

The government issues a Social Forestry policy, a sustainable forest management system implemented in state forest areas or private / customary forests which is carried out by local communities or customary law communities as the main actors to improve welfare, environmental balance and socio-cultural dynamics.[7, hal. 10],[24, hal. 20] Social forestry schemes based on Minister of Forestry Regulation Number 39 of 2013 concerning Partnership, which is renewed by Minister of Forestry Number p.83/menlhk /setjen/kum.1/10/2016 concerning Social Forestry, and 
strengthened by Presidential Regulation Number.88 of 2017 concerning Settlement Tenure of Land in Forest Areas. [6, hal. 1-13]This often creates conflicts between the people who use the forest as their living space and the companies that hold concession permits.

The government aspires to social forestry which is expected to be a part of improving the welfare of communities around forest areas, conserving forests, including reducing conflicts between communities and concession holders. Why forestry partnerships are important, is not only about the policy context, but also about the gap in access between large-scale companies that manage forest resources up to $97 \%$, while the community is only $3 \%$.[25] With this program, the government will later act as a bridge between the community and various parties for peace to resolve conflicts over control of natural resources in forest areas. Making the community a partner with a profit sharing system. Farmers who do not have control over the land can do nothing they have no bargaining value.

Community groups are aware that the existence of social forestry will end with legitimacy for the company's actions in determining the fate of farmers. In the future, the community thinks that the subjugation of the peasants will weaken the struggle of the farmer groups and will gradually expel them from their land. On the other hand, the government did not give the community a choice to choose what the community wanted, the community was only provided with the concept of a cooperation agreement that had been made by the Lampung Provincial Forestry Service. The ongoing Socall forestry is considered not to reflect welfare for farmers who live in the registered forest area. In the theory of the concept of partnership, cross-sector partnerships between representatives of the state, private business and civil society are widely proposed as a way to engage non-state actors in public policies. However, partnerships contain a paradox that prevents effective social regulation or inclusion. Discussants of the partnership debate need to move from rhetoric to identifying institutional designs, maximizing contractual obligations and increasing local consideration or participation. But increasing deliberation also implies seeing how social forestry is reflect/implemented, rather than creating broader norms and advocacy coalitions, and by creating standard means of collaboration such as free, prior and informed consent. Rethinking social forestry, not only accelerating sustainability but also local development that should berun.[14, hal. 1-30],[15, hal. 412],[16, hal. 23] Many people through groups reject or are forced and accept as politics so that people can still find life in the registered forest area of Lampung Province.

\section{Conclusion}

First, the implementation of social forestry must pay attention to the characteristics of the conflict and the function of the forest, so that the social forestry scheme really becomes a bridge to resolve conflicts that occur in the registered forest area of Lampung Province. It must be said that the social forestry that currently exists is not a panacea in all kinds of conflicts in the Lampung Province register (Partnership Not Panacea). Social Forestry Schemes must look at various aspects ranging from, forest functions, legal, social, economic, cultural, political, and identify protected forests starting from: (1) communities, (2) registered land tenants, (3) village officials, (4) security apparatus, (5) government. In production forests, starting from: (1) investors, (2) land providers, (3) land cultivators, (4) partnership groups, (5) non-partnership groups, (6) thugs, (7) companies, (8) officials security, (9) Government. Second, the registered forest area of Lampung Province can 
only run with two schemes, namely Community Forestry and Forestry Partnership, because other forest functions do not exist in Lampung Province. It is necessary to evaluate the implementation of the social forestry program as a program improvement in its subsequent implementation, and become a bridge for conflict resolution.

\section{References}

[1] O. H. Wahab, H. S. Tisnanta, dan Rahayu, "Forest register 45 Mesuji Lampung: Agrarian conflict, social exclusion and human rights violations," Environmental Policy and Law, vol. 48, no. 5, hal. 312-316, 2018.

[2] R. Andreas, "Penyelesaiaan Penguasaan Tanah Di Moro-Moro Register 45 Kabupaten Mesuji," Skripsi Universitas Lampung, 2017.

[3] A. Kusworo, Perambah Hutan atau Kambing Hitam? Potret Sengketa Kawasan Hlitan Di Lampung. Bogor: Pustaka latin, 2000.

[4] O. H. Wahab, "Pengabaian Hak-Hak Konstitusional DalamPerspektif Keadilan (Studi Kasus Warga Moro-moro Register 45, Kabupaten Mesuji Lampung," IUS Kajian Hukum Dan Keadilan, vol. 1, no. $1,2013$.

[5] "No Title."

[6] F. Sumarja dan M. Akib, "Forest Resources Access Moro-Moro Farmers at Register 45 Lampung," Fiat Justisia, vol. 12, no. 1, hal. 1-13, 2018.

[7] F. A.Y., Panduan Praktis Penerapan Kebijakan Perhutanan Sosial. Bogor: Penerbit: Pusat Penelitian Kehutanan Internasional (Cifor), 2018.

[8] "https://lampung.antaranews.com/berita/306840/dishut-lampung-serahkan-pengelolaan-3500hektare-htr diakses 7 april 2020 pukul 17:13 wib.".

[9] K. Harnadi, "Model Penyelesaian Status Hukum Tanah Di Kawasan Hutan Lindung Register 22 Way Waya Yang Di Kuasai Masyarakat Desa Margosari Kabupaten Pringsewu (Tesis)," Universitas Lampung, 2018.

[10] K. Jaka Ferdian, "Model Resolusi Konflik Kawasan Register 45 Mesuji Lampung Berbasis Hutan Tanaman Rakyat," Politika: Jurnal Ilmu Politik, vol. 8, no. 1, hal. 92, 2017.

[11] K. J. Ferdian dan H. Soerjatisnanta, "The Long Road to Partnership: Conflict Resolution of Register 45 Mesuji Lampung," Jurnal Ilmu Sosial dan Ilmu Politik, vol. 20, no. 3, hal. 249, 2017.

[12] R. Andreas, F. X. Sumarja, dan S. Sulastuti, "Kemitraan Akses Hutan Berbasis Kesetaraan Dan Keadilan Di Moro-Moro Register 45 Kabupaten Mesuji Lampung," Jurnal Pusham Unimed, vol. VII, no. KEMITRAAN AKSES HUTAN BERBASIS KESETARAAN DAN KEADILAN DI MORO-MORO REGISTER 45 KABUPATEN MESUJI LAMPUNG, hal. 37-53, 2017.

[13] T. Forsyth, "Panacea or paradox? Cross-sector partnerships, climate change, and development," Wiley Interdisciplinary Reviews: Climate Change, vol. 1, no. 5, hal. 683-696, 2010.

[14] A. Kolk, "Partnerships As A Panacea For Addressing Global Problems? On Rationale, Context, Actors, Impact And Limitation, Article," University Of Amsterdam Business School, The Netherlands, hal. 1-30, 2013.

[15] P. D. McElwee, "Payments for environmental services as neoliberal market-based forest conservation in Vietnam: Panacea or problem?," Geoforum, vol. 43, no. 3, hal. 412-426, 2012.

[16] Bernstein, Mengajukan Pertannyaan Ekonomi-Politik Terkait Relasi Social Dalam Produksi Dan Reproduksi Kapitalis, Yaitu Who Owns What?; Who Does What Gets What?; What Do They Do With It?; Henry Bernstein, Class Dynamics Of Agrarian Change. Kanada: Fernwood Publishing Dan Kumrisn Press, 2010.

[17] S. Sukamto, Pengantar Penelitian Hukum. Jakarta: UI Press, 1983. 
[18] R. S. Wahono, “A Systematic Literature Review of Software Defect Prediction: Research Trends, Datasets, Methods and Frameworks," Journal of Software Engineering, vol. 1, no. 1, 2015.

[19] B. and C. Kitchenham, Guidelines for Performing Systematic Literature Reviews in Software Engineering, Technical Report EBSE 2007-001. Keele University and Durham University Joint Report, 2007.

[20] A. Kusworo, Perambah Hutan Atau Kambing HItam?, vol. 53, no. 9. 2000.

[21] I. B. Santoso, Tesis, Penyelesaian Sengketa Hutan Adat Antara Pt. X Dengan Masyarakat Dayak Bukumpai, Studi Kasus Hutan Adat Desa Kamewen, Kabupaten Barito Utara. Semarang: Magister Kenotariatan Universitas Dipenegoro, 2016.

[22] S. Rahardjo, Ilmu Hukum, Cetakan ke-3. Bandung: PT. Citra Aditya Bakti, 1991.

[23] S. Rahardjo, Hukum dan Masyarakat. Bandung: Penerbit Angkasa, 1997.

[24] Wiratno, "Internalisasi Hutan Desa, Hutan Kemasyarakatan dan Kemitraan: Solusi Konflik, Pengentasan Kemiskinan dan Penyelamatan Habitat dan Perlindungan Keragaman Hayati dalam konteks Pengelolaan Berbasis Adat," in Makalah dalam panel 3 Hutan Adat diantara skema diantara skema pemberdayaan masyarakat, Dialok Nasional, 2014.

[25] "Dokumen Nasional tentang Perhutanan Sosial di Indonesia." 